\title{
PERSISTENT ORGANIC POLLUTANTS IN SERUM AND BREAST MILK OF FERTILE-AGED WOMEN
}

\author{
(Compuestos orgánicos persistentes en suero y leche de mujeres en edad fértil)
}

\author{
Paulina FARÍAS ${ }^{1 *}$, Sandra RODRÍGUEZ-DOZAL ${ }^{1}$, \\ Mary Carmen BALTAZAR-REYES ${ }^{1}$, Gerardo GOLD-BOUCHOT ${ }^{2}$, \\ Omar ZAPATA-PÉREZ ${ }^{3 \dagger}$, Carmen LORETO-GÓMEZ ${ }^{4}$ and Horacio RIOJAS-RODRÍGUEZ ${ }^{1}$
}

${ }^{1}$ Instituto Nacional de Salud Pública, Universidad 655, Col. Santa María Ahuacatitlán, Cerrada Los Pinos y Caminera, 62100 Cuernavaca, Morelos, México

${ }^{2}$ Oceanography Department, Texas A\&M University, 3146 TAMU, College Station, Texas 77843-3146, USA

${ }^{3}$ Centro de Investigación y de Estudios Avanzados-Unidad Mérida, Laboratorio de Geoquímica Marina, km 6 antigua carretera a Progreso, Cordemex, Loma Bonita Xcumpich, 97310 Mérida, Yucatán, México

${ }^{4}$ Universidad Autónoma Metropolitana-Unidad Azcapotzalco, Av. San Pablo Xalpa 180, Col. Reynosa Tamaulipas, 02200 Azcapotzalco, Ciudad de México, México

*Corresponding author: paulina.farias@insp.mx

(Received October 2017; accepted August 2018)

${ }^{\dagger}$ A la memoria del Dr. Omar Zapata, colega y amigo / In memory of Dr. Omar Zapata, colleague and friend

Key words: biomonitoring, DDT, dioxins, PCBs, POPs

\begin{abstract}
Persistent organic pollutants (POPs) can be transferred through the placenta and breast milk to the developing human offspring, carrying immediate and delayed health risks. We sought to evaluate potential levels of exposure to POPs during critical windows of development: pregnancy and lactation. Two cross-sectional studies were carried out in villages of the states of Sonora and Sinaloa in Mexico, where high levels of POPs have been detected through environmental and human monitoring. POPs were measured in the serum of 60 fertile-aged women in the first study. Breast milk POPs concentrations were measured in a pooled sample of 50 women in the second study. This may be the first study in Mexico to report breast milk dioxins' and furans' concentrations. The most commonly detected POPs in serum were: pentachloroanisole (71 \%), PCB 205 (43\%), tetrachlorobenzenes (17-33\%), p,p'DDE (21\%), and toxic lindane by-products $\alpha-\mathrm{HCH}$ or $\beta$-HCH $(15 \%)$. Congeners of furans and dioxins with the highest concentrations in milk were 2,3,4,7,8-PeCDF (3.42 pg/g) and OCDD (33.0 pg/g), respectively. The $\sum \mathrm{PCDD} /$ Fs found in this study was lower than in other studies. Both serum and milk samples of fertile-aged women suggest that p,p'DDE and PCB 180 are prevalent local POPs, among others, that may reach developing embryos and infants via the placenta and lactation. These results can serve as a starting point to determine potential levels of exposure to POPs in the most vulnerable stages of life and to evaluate concentration trends in the process of eliminating these compounds.
\end{abstract}

Palabras clave: biomonitoreo, DDT, dioxinas, PCB, COP 


\section{RESUMEN}

Los compuestos orgánicos persistentes (COP) pueden ser transferidos por la placenta y la leche materna al ser humano en desarrollo, representando un riesgo para su salud a corto y largo plazos. Este trabajo evaluó la exposición potencial a COP durante ventanas críticas del desarrollo. Se realizaron dos estudios transversales en municipios de Sonora y Sinaloa, México, donde se han detectado niveles elevados de COP. En el primer estudio se midieron COP en el suero de 60 mujeres en edad fértil como proxy de la exposición potencial durante el embarazo. En el segundo, se midieron en una muestra agrupada de leche materna de 50 mujeres. Estos podrían ser los primeros resultados publicados de dioxinas y furanos en leche materna en México. Los COP más frecuentemente detectados en suero fueron pentacloroanisol (71 \%), PCB $205(43 \%)$, tetrachlorobencenos (17-33\%), p,p'DDE (21\%) y los isómeros del lindano $\alpha-\mathrm{HCH}$ o $\beta$-HCH $(15 \%)$. Los furanos y dioxinas con mayores concentraciones en leche materna fueron $2,3,4,7,8-\mathrm{PeCDF}(3.42 \mathrm{pg} / \mathrm{g})$ y OCDD $(33.0 \mathrm{pg} / \mathrm{g})$, respectivamente. La $\sum$ $\mathrm{PCDD} /$ Fs encontrada en este estudio fue menor a la de otros. Las mediciones en ambas matrices sugieren que el p,p'DDE y el PCB 180 son COP prevalentes a los que podría haber exposición a través de la placenta y la lactancia. Estos resultados son un punto de partida para evaluar la exposición a COP en etapas vulnerables de la vida, así como las tendencias en las concentraciones de estos compuestos en su proceso de eliminación.

\section{INTRODUCTION}

Persistent organic pollutants (POPs) are carbonbased, resistant to degradation, and lipophilic toxic substances. Since POPs have been massively produce and they accumulate in adipose tissue of living organisms, bioconcentrate in the food chains, and can be transported through long distances, they are widely distributed all over the world (Jones and de Voogt 1999, WHO-UNEP 2016a).

POPs can be classified in organochlorine pesticides (OCPs), polychlorinated biphenyls (PCBs), and dibenzo-p-dioxins (PCDDs) and dibenzofurans (PCDFs). OCPs have been used for agriculture and for controlling vector-transmitted diseases.

PCBs include 209 compounds that have been used as hydraulic and heat exchange fluids, in capacitors and electrical transformers, and as additives in lubricants, paints, and plastics. PCDDs and PCDFs are unintentionally produced by an incomplete combustion and can be by-products in the production of chlorinated substances. They are emitted mostly from incinerators and automobile emissions (Jones and de Voogt 1999, WHO-UNEP 2016a).

Human health effects associated with POPs are many and varied: cardiovascular (Huang et al. 2006, Ljunggren et al. 2014), endocrine (Bonefeld-Jørgensen et al. 2014, Schell et al. 2014), immunologic (Weisglas-Kuperus et al. 2004), metabolic (Dirinck et al. 2014, Tang-Péronard et al. 2015), neurodevelopmental (Lee et al. 2007, Strøm et al. 2014), and reproductive (de Jager et al. 2009, Yang et al. 2015).
Some POPs may also be human carcinogens (Lim et al. 2015, Reaves et al. 2015).

Developing offspring and children may be more vulnerable to POPs because they present unique routes of exposure (transplacental and breast milk) (Needham et al. 2011, Vizcaíno et al. 2014), they go through susceptible phases of development, have immature metabolic pathways, and have more time to acquire a larger body burden and develop effects later in life (Damstra 2002, Falck et al. 2015).

The Stockholm Convention, a global treaty to prohibit or restrict the production and use of POPs, states in its article 11 that the parties are to monitor the presence, levels and trends of POPs in the population (WHO-UNEP 2016b). Mexico, along with the European Union and 178 other nations, is a signing party to the Stockholm Convention (WHO-UNEP 2016c).

This paper comprises two studies done in two northern Mexican states, Sonora and Sinaloa, where exposure to POPs is expected to be considerable, given the past and current local agricultural activities and previous environmental and human monitoring data (Adlard et al. 2014, Cantú-Soto et al. 2011, Meza-Montenegro et al. 2013). Both studies sought to evaluate potential levels of exposure to POPs during critical windows of development.

In the first study, POPs were measured in serum of fertile-aged women to account for the potential burden during pregnancy, since these chemicals can be transferred through the placenta to the developing embryo/fetus. 
The second study measured POPs in maternal milk because it is rich in lipids and the main or sole source of nourishment of lactating infants.

\section{METHODS AND MATERIALS}

Both studies were cross-sectional and conducted in Sonora and Sinaloa villages selected according to their accessibility and population size: Villa Juárez in both studies, along with Bachomobampo and Bahía de Lobos in the serum study, and along with Etchojoa and Huatabampo in the milk study.

Potential participants for each study were identified from the public health centers' censuses of the villages selected. The women who agreed to participate signed informed consents after being briefed about the corresponding study. If a woman was a minor, informed consent was also obtained from her parents or guardians.

The serum study was conducted in 60 fertile-aged, non-pregnant women from August to September 2009. Eligible women were 18-49 years old, had lived in the study area for at least 10 years, were not pregnant, and had no known chronic or important health problems. Recruitment was conducted until a sample size of 20 women from each of the three selected villages was achieved.

The milk study was conducted from February to April 2011 with women who were in postpartum weeks 2-8 and lactating, primiparous, aged 15-30, with a normally developing puerperium, and had lived in the study area for at least 10 years. If the women reported living near incinerators, pulp and paper industries, metal industries or where chemicals were produced, they were not included in the study.

A population sample was fixed at 50 women, according to the preliminary version of the Guidance on the Global Monitoring Plan for Persistent Organic Pollutants (UNEP 2007). Approval of Mexico's National Institute of Public Health's research, ethics, and biosecurity committees was obtained in advance for both studies.

All participants answered questionnaires inquiring socio-demographic characteristics, potential sources of exposure to POPs, and general and reproductive health. The milk study questionnaires were specially designed by UNEP and the Global Environmental Facility (GEF) for POPs monitoring in breast milk studies (UNEP 2010).

Field personnel were trained on standard body measurement techniques prior to the study. Height was measured to the nearest $0.1 \mathrm{~cm}$ with a Seca $(\mathrm{C}$ (model 208) portable stadiometer. Weight was measured in kilograms with a portable solar scale for adults, Tanita $\subseteq$ (model 1631) which measures to the nearest $0.2 \mathrm{~kg}$ for people weighing up to $100 \mathrm{~kg}$, and to the nearest $0.4 \mathrm{~kg}$ for people weighing from 100 to $200 \mathrm{~kg}$. The scale was calibrated daily before using it. Body mass index (BMI) was calculated as weight $(\mathrm{kg}) /$ square height $\left(\mathrm{m}^{2}\right)$.

\section{Serum samples}

Blood samples were drawn from the antecubital vein of each participant and collected in a $10 \mathrm{~mL}$ heparin-containing Vacutainer tube; they were centrifuged to separate the serum and frozen at $-20^{\circ} \mathrm{C}$ until analysis. Serum POPs were analyzed in the Marine Geochemistry Laboratory at the Center for Research and Advanced Studies (CINVESTAV), campus Mérida, Mexico, according to the method of Dale et al. (1970).

Briefly, organochlorine pesticides were extracted and quantified by gas chromatography. Internal standards (200 ng of OCPs) were added to $2.0 \mathrm{~mL}$ of serum, and extracted three times with $6.0 \mathrm{~mL}$ of hexane during $4 \mathrm{~min}$ with a vortex, centrifuged at $2300 \mathrm{rpm}$ for $8 \mathrm{~min}$, and the supernatant extracted with $5.0 \mathrm{~mL}$ of hexane.

The extract was concentrated to $1.0 \mathrm{~mL}$ with a nitrogen flow at a temperature between 20 and 25 ${ }^{\circ} \mathrm{C}$. The extracts were cleaned with $16 \mathrm{~g}$ of partially deactivated Florisil (activated to $600{ }^{\circ} \mathrm{C}$ for $4 \mathrm{~h}$ and partially deactivated with $5 \% \mathrm{w} / \mathrm{w}$ water), packed in a glass column using anhydrous sodium sulfate at the top and bottom of the column.

The first fraction was eluted with $6.0 \mathrm{~mL}$ hexane and the second fraction was eluted with $6.0 \mathrm{~mL}$ of hexane:dichloromethane $(7: 3 \mathrm{v} / \mathrm{v})$. Fractions were evaporated to $50 \mu \mathrm{L}$ with a nitrogen flow.

A total of 26 POPs were quantified by gas chromatography using a Hewlett Packard 5890 Series II gas chromatograph, equipped with an micro electron capture detector and with a $25 \mathrm{~m}$ long, $0.320 \mathrm{~mm}$ of internal diameter with $0.17 \mu \mathrm{m}$ film thicknesses DB-5 (5\% phenyl-methyl-silicone) Ultra2 capillary column.

Temperature program was: initial, $100^{\circ} \mathrm{C}(1 \mathrm{~min})$, final, $300^{\circ} \mathrm{C}$ (rates: $5^{\circ} \mathrm{C} / \mathrm{min}$ up to $140^{\circ} \mathrm{C}, 1.5^{\circ} \mathrm{C} / \mathrm{min}$ up to $250{ }^{\circ} \mathrm{C}, 10.0^{\circ} \mathrm{C} / \mathrm{min}$ up to $300^{\circ} \mathrm{C}$ ). Injector temperature was $275^{\circ} \mathrm{C}$ operated in pulsed splitless mode. Helium was used as the carrier gas at a linear velocity of $1.1 \mathrm{~mL} / \mathrm{min}$.

OCPs were quantified using authentic external standards from Ultra Scientific. Blanks and spiked 
blanks were analyzed simultaneously with each set of samples for quality control and assurance, to check the glassware and chemicals used, and to determine the percent recovery for each batch of samples.

Internal standards added at the beginning of the analyses were used to correct concentrations. To determine the quality of the methods, a recovery study was performed on 10 spiked replicates of blank blood samples, which presented contamination levels below the detection limits.

The fortification study was done with $2 \mathrm{~mL}$ of serum sample with different work solutions $(2.5,5.0$, $10.0,20.0$ y $40.0 \mathrm{ng} / \mathrm{mL}$ ) and showed mean recovery values from 80 to $93 \%$.

\section{Quality control}

Limit of detection (LOD) was defined as mean blank + three times the standard deviation. If a chemical was not found in the blanks, LOD was defined as instrumental detection limit (IDL), which was estimated by injecting low concentrations of target analytes until a small peak at $\sim 3: 1$ signal/noise ratio was obtained.

LODs are expressed in $\mathrm{ng} / \mathrm{mL}$. POPs concentrations were adjusted by estimated lipids, but these were not measured in the samples.

Total serum lipid levels were estimated using Mexico's national total cholesterol and total triglycerides averages in 20 to 60 year-old women: 202.0 and $131.5 \mathrm{mg} / \mathrm{dL}$, respectively, according to the National Survey on Health and Nutrition 2006 (AguilarSalinas et al. 2010). The formula by Phillips et al. (1989) was used to estimate total lipids (equation 1).

Serum lipids $=1.677 \times($ total cholesterol free cholesterol) + free cholesterol +

triglycerides + phospholipids

Free cholesterol is defined as $27 \%$ of total cholesterol, while phospholipids levels were estimated with Phillips (equation 2):

Phospholipids $=0.766 \times$

total cholesterol +0.0623

everything expressed in grams per liter.

\section{POPs in milk}

A $50 \mathrm{~mL}$ milk sample was requested from every participant. Instructions on how to produce the sample were based on UNEP's Standard Operating Procedure for POP Sampling in Breast Milk (UNEP 2010). These instructions were explained orally and also given in a written card to the women.
Participants were asked to wash their hands and breasts thoroughly, using clean water only and no soap, before producing a sample. They were requested not to use ointments on the nipple on the sample-collecting day.

In case the women had applied ointments to the nipple on the sampling day, they should wash it with soap and rinse it thoroughly. Milk collection should be scheduled at the baby's regular feeding time, usually $2 \mathrm{~h}$ after the previous one.

The women could either use manual expression (preferred) or a breast pump to collect hind milk, that is, milk expressed towards the end of each feeding. Milk was directly collected in a special $100 \mathrm{~mL}$ prewashed glass bottle provided by the laboratory that analyzed the samples. In case a woman could not express any milk at the scheduled time, she kept the glass bottle, produced the sample afterward and placed it in her refrigerator.

Study personnel fetched the sample at the woman's home later on the same day or the following morning. All collected samples were transported in coolers with ice packs and stored in a refrigerator at $4{ }^{\circ} \mathrm{C}$ in the health clinic at Villa Juárez for $36 \mathrm{~h}$. Milk samples were then shipped in coolers with ice packs to the National Institute of Public Health in Cuernavaca, Mexico.

Shipment times ranged between 8-10 h and samples were frozen at $-20{ }^{\circ} \mathrm{C}$ upon arrival. When all samples had been collected, each was divided into two $25 \mathrm{~mL}$ portions. A pooled sample was prepared by thawing each sample to room temperature, then vigorously shaking it, and immediately afterward taking a $25 \mathrm{~mL}$ aliquot into a $2000 \mathrm{~mL}$ bottle $(50$ samples $\times 25 \mathrm{~mL}$ each $=1250 \mathrm{~mL}$ ).

The pooled sample was frozen at $-20^{\circ} \mathrm{C}$ and then shipped to the laboratory within $48 \mathrm{~h}$. The remaining $25 \mathrm{~mL}$ of each sample were deep-frozen and stored for future analysis, if possible.

\section{Milk sample analysis}

The pooled milk sample was analyzed by the State Institute for Chemical and Veterinary Analysis of Food (CVUA) in Freiburg, Germany. This laboratory has successfully participated in more than 50 proficiency tests since 1994, with the majority in the past decade.

Among other, the following relevant criteria were met for each batch: reagent blanks were analyzed by performance of a complete analysis using the solvents and reagents, only, in the absence of any sample. Different quality control samples of certified reference material were analyzed. 
Uncontaminated fat samples were analyzed as quality assurance/quality control (QA/QC) samples after spiking of all reported analytes. The recovery rates of the internal standards in the samples, as well as the analytes in the QA/QC samples, were in the range of $70-120 \%$, which met the requirements of the guidelines.

Calibration was based on a multilevel (three or four concentrations) calibration curve including bracketing calibration to control the drift of the relative response (UNEP 2010).

\section{Organochlorine pesticides and PCBs determi- nation}

First, the whole sample was freeze-dried and then, fat and POPs of interest were extracted using a hot extraction device (Twisselmann extractor) with cyclohexane/toluene (50/50) for $8 \mathrm{~h}$. Up to $0.5 \mathrm{~g}$ of the fat extract was re-dissolved in cyclohexane/ethyl acetate and the internal standards (2,4,5-trichlorobiphenly and Mirex), dissolved in cyclohexane, were added.The European standardized methods for pesticide residue analysis for fatty food principles were followed for the cleanup parts of the analytical method followed.

Gel permeation chromatography was performed on a chromatography column using Bio-Beads S-X3 with cyclohexane/ethyl acetate as the eluting solvent to remove fat. For the final cleanup steps after concentration and transfer into iso-octane, chromatography on a small column of partially deactivated silica gel was used with toluene as eluent.

For this, silica gel (70-230 mesh) was heated overnight at $130{ }^{\circ} \mathrm{C}$ and allowed to cool in a desiccator. After adding $1.5 \%$ of water, it was shaken for $30 \mathrm{~min}$ and then stored in a tightly sealed container. The chromatographic tube was packed with $1 \mathrm{~g}$ of deactivated silica gel.

POPs determination was performed with gas chromatography (GC)-electron capture detector using a GC (Fisons Mega 2) with two parallel columns of different polarity (fused silica no. 1:30 m PS-088 [97.5 percent Dimethyl-2.5 percent diphenylsiloxane copolymer] $0.32 \mathrm{~mm}$ id., $0.32 \mu \mathrm{m}$ film thickness, fused silica no. 2:30 m OV-1701-OH, $0.32 \mathrm{~mm}$ id., $0.25 \mu \mathrm{m}$ film thickness, both columns customs column made). The limit of quantification (LOQ) was $0.5 \mathrm{ng} / \mathrm{g}$ fat (UNEP 2017).

\section{PCDDs, PCDFs and PCBs determination}

Lipids, PCDDs, PCDFs and PCBs of interest were extracted from freeze-dried human milk as described above for OCPs and PCB. Once the solvent (cyclohexane/toluene) was evaporated, an aliquot of fat was spiked with C-labeled internal standards (17 PCDD/Fs, 5 non-ortho PCBs [37, 77, 81, 126, 169], 6 mono-ortho PCBs $[28,60,105,118,156,189]$ and 7 di-ortho PCBs [52, 101, 153, 138, 180, 194 and 209]).

By means of gel permeation chromatography on Bio Beads S-X3, fat was removed. The remaining oxidizable substances were removed with a silica column impregnated with sulphuric acid. PCDD/F were separated from PCBs using a florisil column and the PCDD/F-fraction was purified on a Carbopack C-column.

After adding 1,2,3,4-13C12-TCDD, high-resolution gas chromatography/high-resolution mass spectrometry (HRGC/HRMS) was used for the determination (Fisons Autospec; resolution 10000 ; DB5-MS).

The PCBs were separated on a Carbopack Bcolumn into three fractions: di-ortho PCBs (elution with hexane), mono-ortho PCBs (elution with hexane/toluene; 92.5/7.5), and non-ortho PCBs (reversed elution with toluene). Once 13C12-PCB 80 was added, the different PCB groups were determined through HRGC/HRMS (Fisons Autospec; resolution 10 000; DB5-MS) in three separate runs. Marker PCBs were PCB 28, 52, 101, 138, 153 and 180 (UNEP 2017).

\section{Statistical analysis}

Percentages of serum samples with detectable POPs levels were estimated based on their frequency. The prevalence of each POP was considered as the percentage of samples with a detectable level of that specific compound. Serum POPs reported as being below the detection limit were considered as being half the value of the detection limit and analyzed as such. Geometric means, instead of arithmetic ones, were estimated due to the log-normal distribution of serum POPs concentrations. The range of values of each one of the serum POPs was also estimated both for the non-adjusted concentrations and the lipidadjusted ones. Since POPs concentrations in milk were determined from a pooled sample, only a single summary value is reported for each one of them.

Mean differences of each of the serum POPs were analyzed according to the categories of potential predictors using t-tests; linear regressions were used to evaluate the magnitude and direction of the association between continuous levels of each potential determinant and each of the POPs.

All of the statistical analyses of the data were conducted using Stata 10 for Windows (Stata Statistical Software Release 10, 2007). 


\section{RESULTS}

\section{POPs in serum study}

The participating women's age ranged between 19 and 49 years, with a mean of 35 . In regards to smoking, $10 \%$ said they currently smoked and $20 \%$ said they had smoked at some time in their lives. On average, they had three children, were first pregnant at 19 years of age, had either started or completed middle school education, had reportedly been living in the study area for 29 years, had a BMI $=29$, and had a hemoglobin level $=11.8 \mathrm{mg} / \mathrm{dL}$.

Depending on the village of origin, from $15 \%$ (in Villa Juárez) to $40 \%$ (in Bachomobampo) of the women reported burning their household waste as a means of disposing of it. Only in Bahía de Lobos did women (5\%) mentioned using wood as the sole fuel for cooking.

Regarding their occupation, $57 \%$ of the participants reported being homemakers, $32 \%$ reported working in the fields (on average for 7 years), and the rest had diverse occupations. Nonetheless, $91 \%$ declared having done at least temporary work in the fields during the previous year.

Besides working in the fields, another potential source of exposure to OCPs was the use of head lice treatment, reported by $50 \%$ of the women. However, the active ingredient of the product they used was phenothrin, a synthetic pyrethroid. Also, $8 \%$ reported having used a cattle parasiticidal product whose active ingredient was coumaphos, an organophosphate pesticide.

Concentrations of organochlorine compounds and PCBs measured in the serum samples are presented in tables I and II, respectively. Both the highest percentages of detection and the highest levels of POPs were found in Villa Juárez, except for $\alpha-\mathrm{HCH}$, $\gamma-\mathrm{HCH}$, and endosulfan, which showed higher levels in Bahía de Lobos.

Significantly $(\mathrm{p}<0.05)$ higher concentrations of some POPs were seen as age increased (pentachloroanisole, p,p'DDE, mirex, and PCB 7), in those who lived in Villa Juárez compared to living in othervillages,

TABLE I. SERUM CONCENTRATIONS OF ORGANOCHLORINE PESTICIDES IN 60 FERTILE-AGED WOMEN FROM SONORA, MEXICO

\begin{tabular}{|c|c|c|c|c|c|c|}
\hline \multirow{2}{*}{$\begin{array}{l}\text { Organochlorine } \\
\text { pesticide }\end{array}$} & \multirow{2}{*}{$\begin{array}{c}\text { Samples with } \\
\text { a detectable } \\
\text { concentration } \\
(\%)\end{array}$} & \multicolumn{3}{|c|}{$\begin{array}{c}\text { Non-adjusted } \\
\text { concentrations }(\mathrm{ng} / \mathrm{mL})\end{array}$} & \multicolumn{2}{|c|}{$\begin{array}{c}\text { Lipid-adjusted } \\
\text { concentrations (ng/g) }\end{array}$} \\
\hline & & LOD & Range* & GM & Range* & GM \\
\hline $1,2,4,5$ tetrachlorobenzene (TCB) & 17 & 0.016 & BDL, 2.52 & 0.02 & $1.26,385.80$ & 3.12 \\
\hline $1,2,3,4 \mathrm{TCB}$ & 33 & 0.094 & BDL, 2.57 & 0.09 & $7.20,298.73$ & 14.82 \\
\hline Pentachlorobenzene & 9 & 0.103 & BDL, 0.36 & 0.06 & $7.97,54.65$ & 8.93 \\
\hline Hexachlorobenzene (HCB) & 0 & 0.222 & $\mathrm{BDL}$ & NAd & NA & NA \\
\hline$\alpha$-hexachlorocyclohexane $(\mathrm{HCH})$ & 14 & 0.010 & BDL, 1.03 & 0.09 & $0.69,158.40$ & 1.37 \\
\hline$\beta-\mathrm{HCH}$ & 12 & 0.272 & BDL, 2.44 & 0.20 & $20.85,589.41$ & 29.84 \\
\hline $\mathrm{g}-\mathrm{HCH}$ (lindane) & 3 & 0.216 & BDL, 3.73 & NA & $16.55,572.11$ & 18.67 \\
\hline Pentachloroanisole & 71 & 0.011 & BDL, 1.26 & 0.05 & $0.84,192.31$ & 7.75 \\
\hline Heptachlor & 0 & 0.104 & $\mathrm{BDL}$ & NA & NA & NA \\
\hline Aldrin & 2 & 0.232 & BDL, 0.59 & NA & $17.81,90.22$ & 18.29 \\
\hline Hep-epoxy-oxy-chlordane & 3 & 0.204 & BDL, 0.31 & NA & $15.63,47.55$ & 16.21 \\
\hline g-chlordane & 3 & 0.108 & BDL, 0.46 & NA & $8.28,70.64$ & 8.82 \\
\hline$\alpha$-chlordane + PCB 101 & 0 & 0.177 & BDL & NA & NA & NA \\
\hline Trans-nonachlor & 10 & 0.193 & BDL, 0.92 & 0.11 & $7.69,141.42$ & 16.94 \\
\hline Dieldrin & 5 & 0.038 & BDL, 0.82 & NA & $2.91,126.05$ & 3.26 \\
\hline $\mathrm{p}, \mathrm{p}^{\prime}-\mathrm{DDE}$ & 21 & 0.552 & BDL, 13.51 & 0.48 & $42.33,2072.58$ & 74.01 \\
\hline $\mathrm{o}, \mathrm{p}$ '-DDE & 19 & 0.059 & BDL, 1.32 & 0.05 & $4.52,202.49$ & 7.39 \\
\hline$o, p^{\prime}-D D D$ & 3 & 0.571 & BDL, 221.30 & NA & $43.76,339.11$ & 54.6 \\
\hline Endosulfan & 3 & 0.249 & BDL, 0.87 & NA & $19.08,132.89$ & 20.14 \\
\hline Cis-nonachlor & 3 & 0.072 & BDL, 0.54 & NA & $5.18,82.43$ & 5.97 \\
\hline p,p'-DDD + o,p'-DDT+ PCB $132+12$ & 12 & 0.055 & BDL, 0.48 & 0.36 & $4.21,74.16$ & 5.47 \\
\hline Mirex & 12 & 0.055 & BDL, 0.48 & 0.36 & $4.3,74.2$ & 5.47 \\
\hline
\end{tabular}

LOD: limit of detection; BDL: below detection limit; GM: geometric mean; NA: not applicable

*The lower limit of the range was considered as half of the corresponding non-lipid-adjusted LOD divided by the estimated total lipid concentration $(6.52 \mathrm{~g} / \mathrm{L})$ 
TABLE II. SERUM CONCENTRATIONS OF POLYCHLORINATED BIPHENYLS (PCBs) IN 60 FERTILE-AGED WOMEN FROM SONORA, MEXICO

\begin{tabular}{|c|c|c|c|c|c|c|}
\hline \multirow[t]{2}{*}{ PCBs } & \multirow{2}{*}{$\begin{array}{c}\text { Samples with } \\
\text { detectable } \\
\text { concentrations }(\%)\end{array}$} & \multicolumn{2}{|c|}{$\begin{array}{c}\text { Non-adjusted } \\
\text { concentrations (ng/mL) }\end{array}$} & \multicolumn{3}{|c|}{$\begin{array}{c}\text { Lipid-adjusted } \\
\text { concentrations (ng/g) }\end{array}$} \\
\hline & & LOD & Range* & GM & Range* & GM \\
\hline $\mathrm{PCB} 4+10$ & 10 & 0.826 & BDL, 44.58 & 0.48 & $52.3,6833.4$ & 73.43 \\
\hline PCB 7 & 3 & 0.8 & BDL, 0.66 & 0.41 & $61.3,100.6$ & 62.30 \\
\hline PCB $15+18$ & 0 & 0.416 & NA & NA & NA & NA \\
\hline PCB 32 & 7 & 0.329 & BDL, 3.11 & 0.19 & $25.3,477.3$ & 29.61 \\
\hline PCB 28 & 3 & 0.11 & BDL, 0.34 & 0.06 & $8.3,52.3$ & 8.65 \\
\hline PCB 45 & 3 & 0.057 & BDL, 0.29 & 0.03 & $4.4,44.8$ & 4.71 \\
\hline PCB 52 & 0 & 0.565 & NA & NA & NA & NA \\
\hline PCB 41 & 0 & 0.591 & NA & NA & NA & NA \\
\hline PCB 74 & 2 & 0.359 & BDL, 0.98 & 0.19 & $27.6,150.1$ & 28.41 \\
\hline PCB $91+66$ & 0 & 0.359 & NA & NA & NA & NA \\
\hline PCB 56 & 3 & 0.356 & BDL, 0.39 & 0.18 & $27.3,59.9$ & 28.01 \\
\hline PCB 81 & 7 & 0.256 & BDL, 0.77 & 0.14 & $19.6,118.3$ & 21.55 \\
\hline PCB 85 & 2 & 0.352 & BDL, 11.2 & 0.19 & $27.0,1717.5$ & 28.98 \\
\hline РCB 97 & 12 & 0.107 & BDL, 30.25 & 0.08 & $8.3,4636.0$ & 12.84 \\
\hline PCB 114 & 0 & 0.248 & NA & NA & NA & NA \\
\hline PCB 153 & 2 & 0.366 & BDL, 1.32 & 0.19 & $28.1,202.2$ & 29.02 \\
\hline PCB 138 & 0 & 0.607 & NA & NA & NA & NA \\
\hline PCB 167 & 3 & 0.12 & BDL, 3.59 & 0.07 & $9.2,550.0$ & 10.02 \\
\hline PCB 171 & 0 & 0.491 & NA & NA & NA & NA \\
\hline PCB180 & 16 & 0.128 & BDL, 0.21 & 0.08 & $9.8,32.2$ & 11.52 \\
\hline PCB 199 & 3 & 0.026 & BDL, 1.07 & 0.014 & $2.0,163.6$ & 2.19 \\
\hline PCB 205 & 43 & 0.028 & BDL, 1.18 & 0.04 & $2.1,181.3$ & 7.28 \\
\hline
\end{tabular}

LOD: limit of detection; BDL: below detection limit; GM: geometric mean; NA: not applicable

*The lower limit of the range was considered as half of the corresponding non-lipid-adjusted LOD divided by the estimated total lipid concentration $(6.52 \mathrm{~g} / \mathrm{L})$

(hep-epoxy-oxy-chlordane, $\gamma$-chlordane, DDT and its metabolites, trans-nonachlor, mirex, and PCB 7), or in those who worked in agricultural activities compared to those who worked elsewhere (hep-epoxy-oxychlordane, $\gamma$-chlordane, DDT and its metabolites).

Most notably, the mean concentration of $p, p$ 'DDE was $3 \mu \mathrm{g} / \mathrm{g}$ lipid higher in women from Villa Juárez than in women from other villages, and o,p'DDD was $18 \mu \mathrm{g} / \mathrm{g}$ lipid higher in women who worked in agriculture compared to women who worked in other occupations. However no significant differences were seen in POPs's concentrations according to level of education (up to elementary versus higher), cooking with a wood stove compared to cooking with a gas or electric stove, number of pregnancies, or months of breastfeeding.

\section{POPs in milk study}

On average, the participating women's age was 20 years, ranging between 15 and 28. Their offspring's age at the time of the sampling was on average 4.5 weeks, ranging from 3-8 weeks. Seventy-nine percent of women originated from rural villages and $21 \%$ from urban villages. Fifty-five percent of participants reported working before getting pregnant.

Ninety-six percent of the women reported never having smoked, $2 \%$ reported previously smoking and another $2 \%$ reported currently smoking. None of the women reported their homes having ever been sprayed with DDT for vector control.

Lipid adjusted concentrations of OCPs, $\mathrm{PCBs}$, and dioxins and furans measured in the pooled milk sample are reported in tables III, IV, and $\mathbf{V}$, respectively.

\section{DISCUSSION}

Our results represent an initial approach in the estimation of exposure levels to POPs in fertile-aged women as a proxy of what could be expected to reach the developing offspring through the placenta during pregnancy and the nursing infant though breast milk. 
TABLE III. ORGANOCHLORINE PESTICIDES CONCENTRATIONS IN A POOLED BREAST MILK SAMPLE OF 50 PRIMIPAROUS WOMEN IN SONORA, MEXICO

\begin{tabular}{lc}
\hline Organochlorine pesticides & Concentration (ng/g lipid) \\
\hline Aldrin & BDL \\
Chlordane group & BDL \\
$\alpha$-Chlordane & BDL \\
$\gamma$-Chlordane & BDL \\
Oxychlordane & BDL \\
Trans-nonachlor & BDL \\
Dieldrin & 2.1 \\
DDT group & 695.4 \\
o,p'-DDD & BDL \\
p,p'-DDD & 0.6 \\
o,p'-DDE & BDL \\
p,p'-DDE & 606.3 \\
o,p'-DDT & 1.5 \\
p,p'-DDT & 17.2 \\
Endrin group & BDL \\
Endrin & BDL \\
Endrin ketone & BDL \\
Heptachlor group & 0.5 \\
Heptachlor & BDL \\
Cis-heptachlorepoxide & 0.6 \\
Trans-heptachlorepoxide & BDL \\
Hexachlorebenzene & 11.5 \\
\hline
\end{tabular}

BDL: below detection limit

The most prevalent chemical found in serum samples, pentachloroanisole (PCA), is not released directly into the environment; it is a transformation product of pentachlorophenol (PCP), which in turn can be a metabolic product of hexachlorobenzene (HCB) and other organochlorines (Ahlborg et al. 1978, To-Figueras et al. 1997).

PCP has been used extensively as a pesticide in agriculture and as a fungicidal for wood preservation (Seiler 1991). Since serum HCB concentrations were not detected in any of the samples and this is an agricultural area, it is probably safe to assume PCP use is the source of local PCA concentrations.

There is scarce information on the potential health effects of PCA, but an experimental study suggests it may cause morphological deformities, possibly affect the central nervous system's development, and act as a thyroid endocrine disruptor in zebrafish (Cheng et al. 2015). Thus, a more precise identification of sources of exposure to PCA and their elimination is needed.

Also among the most frequently detected compounds in serum were tetrachlorobenzenes $(17-33 \%)$ and PCB 205 (43\%). Despite the fact that there is almost no information on the health effects these
TABLE IV. POLYCHLORINATED BIPHENYLS (PCBs) CONCENTRATIONS IN A POOLED BREAST MILK SAMPLE OF 50 PRIMIPAROUS WOMEN IN SONORA, MEXICO

\begin{tabular}{|c|c|}
\hline $\mathrm{PCBs}$ & $\begin{array}{c}\text { Concentration } \\
\text { (ng/g lipid) }\end{array}$ \\
\hline PCB 28 & 0.667 \\
\hline РCB 52 & 0.127 \\
\hline PCB 101 & 0.156 \\
\hline PCB 138 & 1.020 \\
\hline PCB 153 & 1.500 \\
\hline РCB 180 & 0.888 \\
\hline$\Sigma \mathrm{PCB}$ & 4.358 \\
\hline \multicolumn{2}{|c|}{ Mono-ortho-PCB (ng/g) } \\
\hline PCB 105 & 0.208 \\
\hline PCB 114 & 0.041 \\
\hline PCB 118 & 0.718 \\
\hline PCB 123 & 0.009 \\
\hline РCB 156 & 0.195 \\
\hline PCB 157 & 0.043 \\
\hline PCB 167 & 0.067 \\
\hline PCB 189 & 0.013 \\
\hline \multicolumn{2}{|c|}{ Non-ortho (ng/g) } \\
\hline PCB 77 & 0.005 \\
\hline PCB 81 & 0.001 \\
\hline PCB 126 & 0.006 \\
\hline PCB 169 & 0.003 \\
\hline WHO-mono-ortho PCB-TEQ (pg/g) & 0.24 \\
\hline WHO-non-ortho PCB-TEQ (pg/g) & 0.64 \\
\hline WHO-PCB-TEQ (bound) (pg/g) & $0.87 \pm 0.16$ \\
\hline
\end{tabular}

${ }^{a}$ Since analysis was conducted in a single pooled sample, there is only one bound value

compounds may cause to humans, the known toxicity of chlorobenzenes and PCBs during pregnancy and early development (Mitro et al. 2015) should suffice to take action in order to reduce these potential exposures during critical windows of exposure.

The most commonly found DDT metabolite, dichlorodiphenyldichloroethylene (p,p'DDE), was detected in $21 \%$ of the samples. Although the nonadjusted concentrations found in this study $(\sim 0.28$ $13.51 \mathrm{ng} / \mathrm{mL}$ ) are very similar to those found in a study from 2009 in the Yaqui and Mayo Valleys in children aged $6-12(0.25$ to $10.3 \mathrm{ng} / \mathrm{mL})$, the latter study detected p,p' DDE concentrations in $100 \%$ of the samples (Meza-Montenegro et al. 2013).

Mexico has been conducting activities for more than a decade to phase out lindane (Ramos et al. 2011). Results of these activities can perhaps be seen in the fact that only $5 \%$ of the samples had detectable 
TABLE V. FURANS (PCDF) AND DIOXINS (PCDD) CONCENTRATIONS IN A POOLED BREAST MILK SAMPLE OF 50 PRIMIPAROUS WOMEN IN SONORA, MEXICO

\begin{tabular}{lc}
\hline Furans (PCDF) and or dioxins (PCDD) & Concentration (pg/g) \\
\hline \multicolumn{1}{c}{$2,3,7,8$-substituted PCDF } \\
\hline 2,3,7,8-TCDF (tetrachlorodibenzofuran) & 0.828 \\
1,2,3,7,8-PeCDF (pentachlorodibenzofuran) & 0.447 \\
2,3,4,7,8-PeCDF & 3.420 \\
1,2,3,4,7,8-HxCDF (hexachlorodibenzofuran) & 1.740 \\
1,2,3,6,7,8-HxCDF & 1.660 \\
2,3,4,6,7,8-HxCDF & 0.702 \\
1,2,3,7,8,9-HxCDF & 0.090 \\
1,2,3,4,6,7,8-HpCDF (heptachlorodibenzofuran) & 2.020 \\
1,2,3,4,7,8,9-HpCDF & 0.110 \\
OCDF & 0.369 \\
LPCDF-TEQ & 2.3 \\
\hline & \\
\hline 2,3,7,8-TCDD (tetrachlorodibenzodioxin) & 0.614 \\
1,2,3,7,8-PeCDD (pentachlorodibenzo-p-dioxin) & 1.650 \\
1,2,3,4,7,8-HxCDD (hexachlorodibenzo-p-dioxin) & 0.995 \\
1,2,3,6,7,8-HxCDD & 4.520 \\
1,2,3,7,8,9-HxCDD & 1.510 \\
1,2,3,4,6,7,8-HpCDD (heptachlorodibenzo-p-dioxin) & 9.940 \\
OCDD & 33.00 \\
$\sum P C D D-T E Q$ (toxic equivalence) & 3.1 \\
WHO-PCDD/F-TEQ (bound) & $5.32 \pm 1.03$ \\
\hline
\end{tabular}

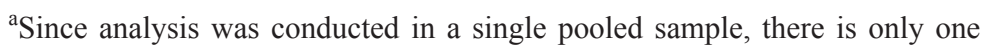
bound value

levels of this compound. This prevalence of detectable lindane is lower than that seen in 2009 in the blood of 6-12 year-old children from the Yaqui and Mayo Valleys, where it was detected in $39 \%$ of the samples (Meza-Montenegro et al. 2013).

It should be noted that LODs in our study for p,p'DDE $(0.55 \mathrm{ng} / \mathrm{mL})$ and lindane $(0.22 \mathrm{ng} / \mathrm{mL})$ were similar to those reported in the study by MezaMontenegro et al. (2013): between 0.2 and $0.5 \mu \mathrm{g} / \mathrm{L}$ for all compounds. However, it is noteworthy that $\alpha-\mathrm{HCH}$ or $\beta-\mathrm{HCH}$ (the other isomers of $\mathrm{HCH}$ and more toxic byproducts of lindane) were present in $15 \%$ of our serum samples.

Trans-nonachlor was present in more serum samples than any other constituent of chlordane $(10 \%)$, but it was not detected in the pooled milk sample. This prevalence of trans-nonachlor is noteworthy because it seems to be the most toxic of all the chlordane components (Bondy et al. 2000). Among the effects of trans-nonachlor seen in rats are hepatic changes and endocrine disruption (Bondy et al. 2004).
PCB 180 was one of the most commonly found PCBs in serum (16\% of the samples), but was much less frequently found than in samples from around the same time in other cities worldwide: $>$ $80 \%$ in the general population of a Sicilian city with an agricultural tradition (Amodio et al. 2012) and $>98 \%$ in Tunisian women (Artacho-Cordón et al. 2015). Still, due to the health effects associated to PCB 180 , like obesity and endocrine disruption (Ferrante et al. 2014), it is important to monitor and reduce its levels.

Serum and milk samples did not come from the same women, they were analyzed by different laboratories with different detection limits, and they were taken with a two-year gap. Yet, examining the concentrations of specific compounds measured in both of these matrices, we see that p,p'DDE and PCB 180 seem to be prevalent pollutants in the area, based on their high percentages of detection and levels.

Therefore, local women are probably exposed to p,p'DDE and PCB 180, thus leading to a prenatal 
exposure to their developing embryos if they become pregnant and to a postnatal exposure of their offspring if they lactate. Milk p,p'DDE concentrations in this study seem to be considerably lower than those found in another study in Yucatan, Mexico, where the mean concentration was $3000 \mathrm{ng} / \mathrm{g}$ (Rodas-Ortiz et al. 2008).

However, the present study found a concentration approximately 600 times higher than that found in the United States, both in women who lived in urban areas $(107 \mathrm{pg} / \mathrm{g})$ and in women who lived in agricultural areas (102 pg/g) (Weldon et al. 2011). Comparing PCBs levels found in milk in this study, a similar situation arose: levels were considerably higher in women from Yucatan, Mexico (Rodas-Ortiz et al. 2008) and lower in women from the United States (Weldon et al. 2011).

In regards to $\mathrm{PCDD} / \mathrm{F}$ concentrations in milk, there is an important lack of information in Mexico. As far as we know, there are no other studies that have measured $\mathrm{PCDD} / \mathrm{F}$ concentrations in human milk in Mexico.

This study represents the first approach to monitoring these compounds. Congeners of furans and dioxins with the highest milk concentrations were $2,3,4,7,8-\mathrm{PeCDF}(3.42 \mathrm{pg} / \mathrm{g})$ and OCDD $(33.0 \mathrm{pg} / \mathrm{g})$, respectively. The $\sum P C D D / F-T E Q$ of our study $(5.32 \mathrm{pg} / \mathrm{g})$ was approximately three times lower than the sum of these compounds found in a similar study done in Brazil with pooled milk samples (15.37 pg/g) (Ferreira and Moreira 2015), and very similar to the mean sum of individual samples reported in a study in China (5.4 pg TEQ/g lipid) (Lu et al. 2015).

A POP that does not appear to be a local problem is heptachlor, since it was not detected in any of the serum or milk samples.

The data on serum POPs concentrations needs to be interpreted cautiously in view of the serum POPs LOD being relatively high; this study's LOD for p,p'DDE was more than twice the LOD of $0.02 \mu \mathrm{g} / \mathrm{L}$ reported by Cupul-Uicab et al. (2010).

Also, in the POPs in serum study, lipids were not measured directly and a single value was used for all based on the best data available, consequently lipid adjusted POPs concentrations are subject to more estimation error.

Regarding the milk POPs results, we don't have information on the individual samples and thus of the range of values. Therefore, we cannot speculate whether some nursing infants in the study area could be assumed to be ingesting breast milk with POPs concentrations above acceptable daily intake values.

\section{CONCLUSIONS}

Considering the information gap on POPs's biological monitoring in Mexico, especially of PCDD/ Fs, this study provides useful information to build on. The toxic effects of POPs justify more in-depth biological monitoring. Moreover, serum samples may serve as a proxy for prenatal exposure during a critical developmental window. On the other hand, human milk is a good indicator of the body burden. Due to its high lipid content, it can accumulate lipophilic compounds and it is relatively easy to obtain through non-invasive methods.

Therefore, more monitoring studies at an individual level and during critical windows of development should be carried out using these matrices to have a more complete picture of the trends and the current state of potential exposure to POPs in the most vulnerable subpopulations. An in-depth analysis of the determinants of POPs's concentrations was beyond the scope and the possibilities of this study, but it is also something that should be investigated.

\section{ACKNOWLEDGMENTS}

The serum study was funded by the Instituto Nacional de Ecología y Cambio Climático (INECC) and the milk study was funded by the United Nations Environmental Program Global Environmental Facility (UNEP-GEF).

We are grateful to all the participants of both studies; to the medical staff from the Centro de Salud Rural de Villa Juárez and the Jurisdicción Sanitaria of Navojoa, Sonora: Ana Patricia Martínez and Miguel Ángel Martínez Cordero. We thank Víctor CejaMoreno from the Centro de Investigación y Estudios Avanzados (CINVESTAV), campus Mérida for his technical help in this article.

\section{REFERENCES}

Adlard B., Davis K., Lian C.L., S Curren M., RodríguezDozal S., Riojas-Rodríguez H., Hernández-Ávila M., Foster W., Needham L., Wong L.Y., Weber J.P., Marro L., Leech T. and Van Oostdam J. (2014). Persistent organic pollutants (POPs) and metals in primiparous women: A comparison from Canada and Mexico. Sci. Total Environ. 500-501, 302-313.

DOI: 10.1016/j.scitotenv.2014.08.074

Aguilar-Salinas C.A., Gómez-Pérez F.J., Rull J., Villalpando S., Barquera S. and Rojas R. (2010). Prevalence 
of dyslipidemias in the Mexican National Health and Nutrition Survey 2006. Salud Pública México 52 (Suppl 1), S44-53.

Ahlborg U.G., Larsson K. and Thunberg T. (1978). Metabolism of pentachlorophenol in vivo and in vitro. Arch. Toxicol. 40 (1), 45-53. DOI: 10.1007/BF00353278

Amodio E., Turci R., Massenti M. F., Di Gaudio F., Minoia C., Vitale F., Firenze A. and Calamusa G. (2012). Serum concentrations of persistent organic pollutants (POPs) in the inhabitants of a Sicilian city. Chemosphere 89 (8), 970-974.

DOI: 10.1016/j.chemosphere.2012.06.054

Artacho-Cordón F., Belhassen H., Arrebola J.P., Ghali R., Amira D., Jiménez-Díaz I., Pérez-Lobato R., Boussen H., Hedili A. and Olea N. (2015). Serum levels of persistent organic pollutants and predictors of exposure in Tunisian women. Sci. Total Environ. 511, 530-534. DOI: 10.1016/j.scitotenv.2014.12.093

Bondy G.S., Newsome W.H., Armstrong C.L., Suzuki C.A.M., Doucet J., Fernie S., Hierlihy S.L., Feeley M.M. and Barker M.G. (2000). Trans-nonachlor and cis-nonachlor toxicity in Sprague-Dawley rats: Comparison with technical chlordane. Toxicol. Sci. 58 (2), 386-398. DOI: $10.1093 /$ toxsci/58.2.386

Bondy G.S., Curran I., Doucet J., Armstrong C., Coady L., Hierlihy L., Fernie S., Robertson P. and Barker M. (2004). Toxicity of trans-nonachlor to Sprague-Dawley rats in a 90-day feeding study. Food Chem. Toxicol. 42 (6), 1015-1027. DOI: 10.1016/j.fct.2004.02.014

Bonefeld-Jørgensen E.C., Ghisari M., Wielsøe M., Bjerregaard-Olesen C., Kjeldsen L.S. and Long M. (2014). Biomonitoring and hormone-disrupting effect biomarkers of persistent organic pollutants in vitro and ex vivo. Basic Clin. Pharmacol. Toxicol. 115 (1), 118-128. DOI: 10.1111/bcpt.12263

Cantú-Soto E.U., Meza-Montenegro M.M., ValenzuelaQuintanar A.I., Félix-Fuentes A., Grajeda-Cota P., Balderas-Cortes J.J., Osorio-Rosas C.L., Acuña-García G. and Aguilar-Apodaca M.G. (2011). Residues of organochlorine pesticides in soils from the southern Sonora, Mexico. Bull. Environ. Contam. Toxicol. 87 (5), 556-560. DOI: 10.1007/s00128-011-03535Cheng Y., Ekker M. and Chan H.M. (2015). Relative developmental toxicities of pentachloroanisole and pentachlorophenol in a zebrafish model (Danio rerio). Ecotoxicol. Environ. Saf. 112, 7-14. DOI: 10.1016/j.ecoenv.2014.10.004

Cupul-Uicab L.A., Hernández-Ávila M., Terrazas-Medina E.A., Pennell M.L. and Longnecker M.P. (2010). Prenatal exposure to the major DDT metabolite 1,1-dichloro-2,2-bis(p-chlorophenyl)ethylene (DDE) and growth in boys from Mexico. Environ. Res. 110 (6), 595-603. DOI: 10.1016/j.envres.2010.06.001
Dale W.E., Miles J.W. and Gaines T.B. (1970). Quantitative method for determination of DDT metabolites in blood serum. J. Assoc. Off. Anal. Chem. 53, 12871292.

Damstra T. (2002). Potential effects of certain persistent organic pollutants and endocrine disrupting chemicals on the health of children. J. Toxicol.-Clin. Toxic. 40 (4), 457-465. DOI: 10.1081/CLT-120006748

De Jager C., Aneck-Hahn N.H., Bornman M.S., Farias P., Leter G., Eleuteri P., Rescia M. and Spanò M. (2009). Sperm chromatin integrity in DDT-exposed young men living in a malaria area in the Limpopo Province, South Africa. Hum. Reprod. 24 (10), 2429-2438.

DOI: $10.1093 /$ humrep/dep249

Dirinck E.L., Dirtu A.C., Govindan M., Covaci A., Van Gaal L.F. and Jorens P.G. (2014). Exposure to persistent organic pollutants: relationship with abnormal glucose metabolism and visceral adiposity. Diabetes Care 37 (7), 1951-1958. DOI: 10.2337/dc13-2329

Falck A.J., Mooney S., Kapoor S.S., White K.M.R., Bearer C. and El Metwally D. (2015). Developmental exposure to environmental toxicants. Pediatr. Clin. N. Am. 62 (5), 1173-1197. DOI: 10.1016/j.pcl.2015.05.005

Ferrante M.C., Amero P., Santoro A., Monnolo A., Simeoli R., Di Guida F., Mattace R.G. and Meli R. (2014). Polychlorinated biphenyls (PCB 101, PCB 153 and PCB 180) alter leptin signaling and lipid metabolism in differentiated 3T3-L1 adipocytes. Toxicol. Appl. Pharmacol. 279 (3), 401-408. DOI: 10.1016/j.taap.2014.06.016

Ferreira A.P. and Moreira M. (2015). Dioxins and furans in breast milk: A case study of mothers from southern Rio de Janeiro, Brazil. Cad. Saude Publica 31 (5), 1107-1111.

DOI: 10.1590/0102-311X00052914

Huang X., Lessner L. and Carpenter D.O. (2006). Exposure to persistent organic pollutants and hypertensive disease. Environ. Res. 102 (1), 101-106.

DOI: $10.1016 /$ j.envres.2005.12.011

Jones K.C. and de Voogt P. (1999). Persistent organic pollutants (POPs): State of the science. Environ. Pollut. 100 (1-3), 209-221.

DOI: $10.1016 / \mathrm{S} 0269-7491(99) 00098-6$

Lee D.H., Jacobs D.R. and Porta M. (2007). Association of serum concentrations of persistent organic pollutants with the prevalence of learning disability and attention deficit disorder. J. Epidemiol. Commun. H. 61 (7), 591-596. DOI: $10.1136 /$ jech.2006.054700

Lim J., Park S.H., Jee S.H. and Park H. (2015). Body concentrations of persistent organic pollutants and prostate cancer: A meta-analysis. Environ. Sci. Pollut. Res. Int. 22 (15), 11275-11284.

DOI: $10.1007 / \mathrm{s} 11356-015-4315-\mathrm{z}$ 
Ljunggren S.A., Helmfrid I., Salihovic S., Bavel B., Wingren G., Lindahl M. and Karlsson H. (2014). Persistent organic pollutants distribution in lipoprotein fractions in relation to cardiovascular disease and cancer. Environ. Int. 65, 93-99. DOI: 10.1016/j.envint.2013.12.017

Lu D., Lin Y., Feng C., Wang D., She J., Shen H., Wang G. and Zhou Z. (2015). Levels of polychlorinated dibenzo-p-dioxins/furans (PCDD/Fs) and dioxin-like polychlorinated biphenyls (DL-PCBs) in breast milk in Shanghai, China: A temporal upward trend. Chemosphere 137, 14-24.

DOI: 10.1016/j.chemosphere.2015.04.043

Meza-Montenegro M.M., Valenzuela-Quintanar A.I., Balderas-Cortés J.J., Yañez-Estrada L., GutiérrezCoronado M.L., Cuevas-Robles A. and Gandolfi A.J. (2013). Exposure assessment of organochlorine pesticides, arsenic, and lead in children from the major agricultural areas in Sonora, Mexico. Arch. Environ. Contam. Toxicol. 64 (3), 519-527.

DOI: $10.1007 / \mathrm{s} 00244-012-9846-4$

Mitro S.D., Johnson T. and Zota A.R. (2015). Cumulative chemical exposures during pregnancy and early development. Curr. Environ. Health Rep. 2 (4), 367-378. DOI: $10.1007 / \mathrm{s} 40572-015-0064-\mathrm{x}$

Needham L.L., Grandjean P., Heinzow B., Jørgensen P.J., Nielsen F., Patterson D. G., Sjödin A., Turner W.E. and Weihe P. (2011). Partition of environmental chemicals between maternal and fetal blood and tissues. Environ. Sci. Technol. 45 (3), 1121-1126.

DOI: $10.1021 /$ es1019614

Phillips D.L., Pirkle J.L., Burse V.W., Bernert J.T., Henderson L.O. and Needham L.L. (1989). Chlorinated hydrocarbon levels in human serum: Effects of fasting and feeding. Arch. Environ. Contam. Toxicol. 18 (4), 495-500. DOI: 10.1007/BF01055015

Ramos J., Gavilán A., Romero T. and Ize I. (2011). Mexican experience in local, regional and global actions for lindane elimination. Environ. Sci. Policy 14 (5), 503-509. DOI: 10.1016/j.envsci.2011.03.014

Reaves D.K., Ginsburg E., Bang J.J. and Fleming J.M. (2015). Persistent organic pollutants and obesity: Are they potential mechanisms for breast cancer promotion? Endocr. Relat. Cancer 22 (2), R69-86.

DOI: 10.1530/ERC-14-0411

Rodas-Ortiz J.P., Ceja-Moreno V., González-Navarrete R.L., Alvarado-Mejía J., Rodríguez-Hernández M.E. and Gold-Bouchot G. (2008). Organochlorine pesticides and polychlorinated biphenyls levels in human milk from Chelem, Yucatan, Mexico. Bull. Environ. Contam. Toxicol. 80 (3), 255-259.

DOI: $10.1007 / \mathrm{s} 00128-007-9356-7$

Schell L.M., Gallo M.V., Deane G.D., Nelder K.R., DeCaprio A.P., Jacobs A. and the Akwesasne Task
Force on the Environment (2014). Relationships of polychlorinated biphenyls and dichlorodiphenyldichloroethylene (p,p'-DDE) with testosterone levels in adolescent males. Environ. Health Perspect. 122 (3), 304-309. DOI: 10.1289/ehp.1205984

Seiler J.P. (1991). Pentachlorophenol. Mutat. Res.-Rev. Genet. 257 (1), 27-47.

DOI: 10.1016/0165-1110(91)90018-Q

Strøm M., Hansen S., Olsen S.F., Haug L.S., Rantakokko P., Kiviranta H. and Halldorsson T.I. (2014). Persistent organic pollutants measured in maternal serum and offspring neurodevelopmental outcomes-a prospective study with long-term follow-up. Environ. Int. 68, 41-48. DOI: 10.1016/j.envint.2014.03.002

Tang-Péronard J.L., Heitmann B.L., Jensen T.K., Vinggaard A.M., Madsbad S., Steuerwald U., Grandjean P., Weihe P., Nielsen F. and Andersen H.R. (2015). Prenatal exposure to persistent organochlorine pollutants is associated with high insulin levels in 5-year-old girls. Environ. Res. 142, 407-413.

DOI: 10.1016/j.envres.2015.07.009

To-Figueras J., Sala M., Otero R., Barrot C., SantiagoSilva M., Rodamilans M., Herrero C., Grimalt J. and Sunyer J. (1997). Metabolism of hexachlorobenzene in humans: Association between serum levels and urinary metabolites in a highly exposed population. Environ. Health Perspect. 105 (1), 78-83.

UNEP (2007). Guidance on the global monitoring plan for persistent organic pollutants. Preliminary version. United Nations Environment Programme. Geneva, Switzerland, $146 \mathrm{pp}$.

UNEP (2010). Standard operating procedure for POP sampling in breast milk. United Nations Environment Programme. Geneva, Switzerland, $20 \mathrm{pp}$.

UNEP (2017). UNEP-coordinated survey of mothers' milk for persistent organic pollutants. Guidelines for organization, sampling and analysis. United Nations Environment Programme. Geneva, Switzerland, $38 \mathrm{pp}$.

Vizcaíno E., Grimalt J.O., Fernández-Somoano A. and Tardon A. (2014). Transport of persistent organic pollutants across the human placenta. Environ. Int. 65, 107-115. DOI: 10.1016/j.envint.2014.01.004

Weisglas-Kuperus N., Vreugdenhil H.J.I. and Mulder P.G.H. (2004). Immunological effects of environmental exposure to polychlorinated biphenyls and dioxins in Dutch school children. Toxicol. Lett. 149 (1-3), 281285. DOI: 10.1016/j.toxlet.2003.12.039

Weldon R.H., Barr D.B., Trujillo C., Bradman A., Holland N. and Eskenazi B. (2011). A pilot study of pesticides and PCBs in the breast milk of women residing in urban and agricultural communities of California. J. Environ. Monit. 13 (11), 3136-3144.

DOI: $10.1039 / \mathrm{c} 1 \mathrm{em} 10469 \mathrm{a}$ 
WHO-UNEP (2016a). The POPs. World Health Organization-United Nations Environment Programme [online]. http://chm.pops.int/TheConvention/ThePOPs/ tabid/673/Default.aspx 10/08/2016

WHO-UNEP (2016b). Text of the convention. World Health Organization and United Nations Environment Programme [online]. http://chm.pops.int/TheConvention/Overview/TextoftheConvention/tabid/2232/ Default.aspx 10/08/2016
WHO-UNEP (2016c). Status of ratifications of the Stockholm Convention. World Health Organization and United Nations Environment Programme [online]. http://chm.pops.int/Countries/StatusofRatifications/PartiesandSignatoires/tabid/4500/Default. aspx 10/08/2016

Yang Q., Zhao Y., Qiu X., Zhang C., Li R. and Qiao J. (2015). Association of serum levels of typical organic pollutants with polycystic ovary syndrome (PCOS): A case-control study. Hum. Reprod. 30 (8), 1964-1973. DOI: $10.1093 /$ humrep/dev123 